\title{
Pemanfaatan Limbah Sayur dalam Formulasi Ransum Ayam Broiler
}

\author{
Wahyu Mushollaeni ${ }^{1 *}$, Eka Fitasari ${ }^{2}$ \\ ${ }^{1}$ Program Studi Teknologi Industri Pertanian, Universitas Tribhuwana Tunggadewi \\ ${ }^{2}$ Program Studi Peternakan, Universitas Tribhuwana Tunggadewi \\ *Correspoding Author: wahyu.mushollaeni@gmail.com
}

\begin{abstract}
ABSTRAK
Permasalahan utama yang dihadapi peternak ayam Sumber Rejeki adalah penyediaan pakan yang memenuhi kebutuhan nutrisi, namun harganya terjangkau. Pada sisi yang lain, kelompok petani Siswandi dihadapkan pada permasalahan dengan banyaknya limbah sayur yang low grade dan bagian sayur yang tidak dapat dikonsumsi manusia. Limbah sayur yang menumpuk dan busuk, dapat menjadi penyebab pencemaran lingkungan dan bau yang menyengat di tempat pembuangan sampah. Oleh karenanya, sebagai alternatif untuk mengurangi potensi pencemaran sekaligus menjalin kerjasama yang saling menguntungkan dalam pemecahan masalah maka perlu adanya pemanfaatan limbah sayur menjadi bahan baku pelet pakan ayam broiler. Kegiatan pengabdian masyarakat ini bertujuan untuk mengaplikasikan pakan dari limbah sayur petani dan meningkatkan produksi ternak dengan parameter tingkat efisiensi pakan (FCR), mortalitas, dan peningkatan bobot badan. Penyuluhan dan praktek langsung pembuatan pelet, pendampingan selama pemeliharaan, dan pengamatan hasil terhadap produksi broiler dilakukan pada kelompok peternak. Tiga jenis limbah sayur dengan jumlah terbanyak yang digunakan sebagai bahan baku pelet yaitu kubis, daun kol putih, dan sawi. Hasil kegiatan menunjukkan bahwa terjadi peningkatan pengetahuan dan keterampilan lebih dalam serta pengelolaan usaha tani yang lebih baik pada pemanfaatan limbah sayur menjadi pelet pakan ayam broiler.
\end{abstract}

Kata kunci: pengelolaan usaha tani, ayam broiler, nilai ekonomis, limbah sayur

\begin{abstract}
The main problem faced by Sumber Rejeki chicken farmers is the provision of feed that meets nutritional needs but at an affordable price. On the other hand, the Siswandi farmer group is faced with a problem with a large amount of low-grade vegetable waste and parts of vegetables that cannot be consumed by humans. Vegetable waste that has accumulated and is rotten, can cause environmental pollution and a pungent odor in landfills. Therefore, as an alternative to reduce the potential for pollution and the occurrence of mutually beneficial cooperation to solve common problems is to use vegetable waste as raw material for broiler chicken feed pellets. This community service activity aims to apply feed from farmer's vegetable waste and increase livestock production with the parameters of the level of feed efficiency $(F C R)$, mortality, and increased body weight. Extension and direct practice of making pellets, assistance during maintenance, and observing the results of broiler production are carried out in farmer groups. Three types of vegetable waste with the highest amount, namely cabbage, white cabbage leaves, and mustard greens are used as raw materials for pellets. The results of the activity showed that there was an increase in knowledge and skills in better farming management in the use of vegetable waste into broiler chicken feed pellets.
\end{abstract}

Keywords: farming management, broiler chicken, economic value, vegetable waste

\section{PENDAHULUAN}

Peningkatan jumlah penduduk harus diiringi dengan peningkatan penyediaan sumber protein, hal ini penting, karena peningkatan gizi pada masyarakat akan berkorelasi dengan peningkatan kualitas dari generasi muda. Selama ini, pemenuhan sumber protein dapat berasal dari bidang perikanan maupun peternakan. Dalam bidang peternakan, sumber protein tidak 
hanya diperoleh dari daging merah saja, yaitu dari daging sapi, namun juga dipenuhi dari daging ternak yang lain yaitu dari daging babi, kambing atau domba, dan unggas. Dibandingkan dengan daging yang lain, daging unggas yaitu daging ayam broiler berdasarkan jumlahnya masih berada pada urutan teratas dalam hal memenuhi kebutuhan akan daging bagi masyarakat Indonesia. Hal ini wajar, karena harganya yang memang jauh lebih murah dibandingkan harga per kilogram daging yang lain.

Jumlah populasi unggas di Indonesia setiap tahun semakin meningkat, fakta ini juga didukung oleh pengembangan kemitraan yang terjalin antara perusahaan perunggasan dan masyarakat Indonesia. Tentunya ini akan berimbas pada tuntutan sumber pakan untuk memenuhi populasi unggas yang banyak tersebut. Ditegaskan pula oleh (Sunarminto, 2010) bahwa keberhasilan usaha peternakan, salah satunya ditentukan oleh ketersediaan pakan yang cukup bagi ternaknya. Berbagai alternatif dilakukan oleh peternak untuk menyediakan pakan bagi ternaknya di masa pendemi akibat harga pakan yang tidak menentu. Alternatif sumber pakan tersebut dapat digunakan sebagai pakan unggas dengan syarat sumber pakan alternatif ini dapat diperoleh dengan mudah dan tidak menambah beban biaya pakan. Salah satu alternatif sumber pakan yang murah adalah limbah sayur.

Limbah sayur dapat berasal dari limbah pertanian sayur untuk konsumsi manusia maupun jenis-jenis sayur yang tidak layak untuk dijual. Berdasarkan hasil wawancara dengan petani yang bekerja sebagai pemasok sayur ke pedagang atau supermarket, jumlah limbah sayur ini cukup banyak setiap harinya. Jenis limbah sayur tersebut diantarnya daun kol putih, daun brokoli, dan kubis. Jenis sayur ini mempunyai bagian daun terluar yang menempel saat sayur dipanen seperti pada kol putih ataupun brokoli. Jika bagian daun ini dipisahkan dari bagian sayur utama, akan menghasilkan limbah daun yang cukup banyak. Jumlah sayuran yang tidak layak jual, jumlahnya juga cukup banyak, contohnya sayur kubis, sayur sawi, sayur pakcoy, dan sayur selada. Padahal menurut hasil penelitian dari beberapa peneliti, diantaranya oleh (Abun et al., 2007; Bakshi et al., 2016; Das et al., 2019; Truong et al., 2019), menjelaskan bahwa limbah sayur masih mengandung kadar protein $10-19 \%$ atau dalam penelitian lain 9$11 \%$ dan bahkan ada yang mencapai $24 \%$.
Limbah sayur tersebut jika ditambahkan bahanbahan pelengkap pakan dan mineral, maka sangat berpotensi untuk dijadikan bahan baku pakan ternak ayam. Kelebihan lainnya jika menggunakan limbah sayuran adalah dapat mensubtitusi sebagian penggunaan jagung dan kedelai sebagai bahan baku utama pakan ternak, sehingga sebagian penggunaan jagung dan kedelai dapat dialihkan pada industri pengolahan lainnya. Ditambahkan oleh Md Salim et al. (2017), pengolahan limbah yang berasal dari sayuran dapat memberikan dampak positif secara berkelanjutan untuk lingkungan. Permasalahan lingkungan akan muncul, apabila limbah-limbah sayur tersebut hanya sekedar dibuang saja, karena akan menambah massa sampah di TPA (Tempat Pembuangan Akhir). Superianto et al. (2018) menguatkan dengan pernyataannya bahwa limbah pasar yang berupa sayuran dapat menyumbang polusi bagi lingkungan pasar, menimbulkan bau busuk, dan dapat mengakibatkan penyakit. Oleh karena itu, limbah sayur ini perlu diolah lagi menjadi alternatif bahan pakan ternak terutama untuk ayam, sehingga akan membantu menurunkan biaya pembelian pakan pabrik, harganya murah, berkualitas baik, dan mudah didapat.

Realita yang dihadapi oleh sektor pertanian di Indonesia adalah masih banyaknya kelompok petani dan peternak yang ada di masyarakat yang belum mampu meningkatkan kualitas dan kuantitas produksinya. Kelompok petani masih lebih banyak bergantung pada hasil pertanian sebagai sumber upendapatan utama tanpa memperhatikan pengelolaan limbah yang dihasilkan dari usaha pertaniannya misalnya sisa sayur low grade atau limbah sayur lainnya. Kondisi yang hampir sama juga terjadi pada para peternak atau kelompok peternak yang rata-rata belum mampu mengelola usahanya dengan memanfaatkan potensi yang ada atau bekerjasama dengan kelompok tani yang lain. Sebagian besar peternak ayam skala kecil yang ada di masyarakat, hanya mengandalkan pakan ternaknya pada pakan jadi atau sisa bahan pangan konsumsi manusia. Oleh karenanya, sangat dibutuhkan pemberdayaan kelompok tani kecil yang ada di masyarakat dalam bentuk usaha sinergis antar kelompok tani, sehingga dapat mendorong penciptaan dan pengembangan usaha tani yang lebih maju dan produktif.

Lowisada, (2014) menyatakan bahwa pemberdayaan kelompok tani diperlukan untuk membantu peningkatan pendapatan usahatani dan mengatasi permasalahan pertanian yang 
dihadapi oleh kelompok tani. Pernyataan ini juga dikuatkan oleh Widjajanti (2011), pelibatan kelompok masyarakat dalam pelaksanaan program, akan mendorong pencapaian tujuan program yang lebih baik. Kelompok petani sayur umumnya, dan yang ada di Kabupaten Malang khususnya, rata-rata menghasilkan limbah sayur yang cukup besar dari hasil panennya. Limbah hasil pertanian tersebut berupa bagian tanaman yang tidak digunakan untuk konsumsi manusia contohnya daun brokoli, daun kubis bagian luar, serta sayuran yang tergolong low grade karena cacat saat penanganan pascapanen, pemanenan, dan karena serangan serangga. Kerusakan karena penanganan pascapanen yang tidak tepat, akan berakibat pada penurunan kualitas sayur dan daya simpan yang semakin pendek. Kerusakan pascapanen tersebut mencapai 2528\% (Siswadi, 2007). Selain itu, ditambahkan oleh Samad (2006), sayuran merupakan salah satu komoditas hortikultura yang bersifat mudah rusak, sehingga jika tidak ditangani dengan baik setelah panen akan mengakibatkan turunnya nilai ekonomis dan nilai gizinya.

Tumpukan limbah sayur ini dapat berpotensi menjadi limbah yang dapat mengganggu lingkungan, terutama pada sayuran yang mengandung protein dan kadar air tinggi. Limbah sayur yang mengandung protein tinggi dapat menghasilkan bau menyengat, sedangkan limbah sayur yang mengandung kadar air tinggi seperti kubis dan kol dapat menjadi sumber pencemaran lingkungan. Berdasarkan persoalan tersebut, maka sangat penting untuk menerapkan teknologi pengolahan kreatif yang mudah dan murah untuk mengatasi masalah tersebut (Mulyono, 2014; Rusad \& Santosa, 2016). Di sisi lainnya, para peternak kecil yang ada di masyarakat, lebih banyak mengandalkan pakan dari limbah pangan konsumsi dan pakan jadi yang dibeli di toko pakan ternak. Harga pakan yang naik turun seiring dengan kenaikan harga bahan baku, juga menjadi masalah yang cukup berat bagi para peternak kecil untuk mengembangkan usahanya. Diantara kelompok peternak dan petani yang ada di Kabupaten Malang adalah kelompok usaha ternak Sumber Rejeki dan kelompok petani sayur Siswandi.

Kelompok usaha ternak Sumber Rejeki yang berada di daerah Singosari Kabupaten Malang dan kelompok petani sayur Siswandi yang berada di daerah Pujon merupakan salah satu contoh kelompok tani kecil yang ada di masyarakat. Namun demikian, kedua kelompok tani tersebut cukup produktif dan mempunyai kemungkinan yang besar untuk berkembang menjadi usaha mandiri masyarakat. Harapan besar dari kedua kelompok tani tersebut adalah adanya pendampingan dan pembimbingan usaha yang dapat meningkatkan pengetahuan dan keterampilan lebih dalam terkait pengelolaan usaha tani yang lebih baik, serta dimungkinkannya adanya tambahan pendapatan yang diperoleh dari pengelolaan atau pengolahan hasil pertanian.

Limbah sayur atau sayuran low grade yang dihasilkan oleh mitra kelompok tani diantaranya adalah dari jenis daun brokoli, sawi daging, daun kembang kol, lettuce, kubis, dan sawi putih. Hasil analisis laboratorium menyatakan bahwa persentase kadar protein, serat kasar, dan lemak secara berturutan berkisar antara 16,97\%-38,82\%; 12,01-14,67\%; dan $2,29-5,82 \%$. Kadar protein tertinggi terdapat pada daun kembang kol yaitu 38,82\% dan terendah pada sawi putih yaitu $16,97 \%$. Kadar lemak tertinggi adalah pada daun brokoli $5,82 \%$ dan yang terendah pada sawi putih 2,29\%. Sedangkan kubis mempunyai kadar serat kasar tertinggi yaitu 14,67\% dan daun kembang kol mempunyai kadar yang terendah yaitu $12,01 \%$. Persentase bahan kering dalam limbah sayur berkisar 86,31-92,28\%. Data kandungan gizi sayur tersebut digunakan sebagai dasar dalam penyusunan pelet pakan ayam.

Hasil analisis awal yang dilakukan terhadap kedua kelompok tani tersebut menunjukkan beberapa permasalahan utama yaitu: (1) kualitas pakan yang masih rendah dan beragam, sehingga berakibat pada produktivitas dan produksi ayam menjadi rendah; (2) belum adanya ketersediaan pakan yang mencukupi, murah, dalam bentuk pelet, dan dapat disimpan dalam jangka waktu yang lama; (3) penanganan pascapanen sayuran yang masih dapat menimbulkan kerusakan pascapanen hingga $40 \%$, sehingga sisa sayur low grade melimpah, berpotensi menjadi limbah, dan penurunan pendapatan; serta (4) belum ada teknologi untuk memanfaatkan limbah sayur menjadi suatu produk yang dapat menambah pendapatan bagi petani sayur. Berdasarkan permasalahan tersebut, tim Pengabdian Kepada Masyarakat (PKM) dari Program Studi Teknologi Industri Pertanian dan Peternakan UNITRI merancang mesin pembuat pakan berbentuk pelet dari limbah sayur, kemudian bersama tim dari Program Studi Peternakan menyusun komposisi ransum ayam broiler menggunakan ketiga jenis limbah sayur yang dihasilkan oleh kelompok 
tani Siswandi, dan mengaplikasikan pakan tersebut pada ayam broiler yang diternakkan oleh kelompok tani Sumber Rejeki. Kegiatan pengabdian masyarakat ini bertujuan untuk mengaplikasikan pakan dari limbah sayur petani dan meningkatkan produksi ternak dengan parameter tingkat efisiensi pakan (FCR), mortalitas, dan peningkatan bobot badan. Diharapkan dampaknya dapat meningkatkan pengetahuan dan keterampilan lebih dalam mengenai pengelolaan usaha tani yang lebih baik, serta dimungkinkannya adanya tambahan pendapatan yang diperoleh dari pengelolaan atau pengolahan hasil pertanian yang dihasilkan.

\section{METODE}

Kegiatan PKM dilakukan bersama dan sinergis dengan Kelompok Tani Siswandi dan Sumber Rejeki. Kelompok Tani Siswandi adalah kelompok tani yang jenis usahanya budidaya dan penjualan aneka jenis sayur, sedangkan Kelompok Tani Sumber Rejeki adalah kelompok tani yang mempunyai usaha peternakan ayam dan burung hias. Lokasi Kelompok Tani Siswandi adalah di Pujon, Kabupaten Malang, sedangkan Kelompok Tani Sumber Rejeki berada di daerah Singosari dan Landungsari,
Kabupaten Malang. Tim PKM UNITRI merancang mesin pembuat pelet pakan dan dibantu oleh tim mitra PKM untuk memformulasikan komposisi limbah sayur yang digunakan sebagai pakan ayam broiler milik Kelompok Tani Sumber Rejeki.

Kelompok Tani Siswandi sebagai penyedia sumber limbah sayur dan sayuran low atau under grade menyuplai kebutuhan bahan baku pembuatan pakan ayam berbentuk pelet. Kedua kelompok tani akan dibekali pengetahuan dan keterampilan yang sama untuk pembuatan pakan ayam berbentuk pelet yang diberasal dari limbah sayur. Kelompok tani juga dibekali pengetahuan tentang penentuan formulasi dan jenis sayur yang paling baik untuk bahan baku pembuatan pakan ayam berbentuk pelet. Monitoring pelaksanaan program dilakukan secara terjadwal sesuai kesepakatan bersama antara tim PKM UNITRI dengan tim mitra. Evaluasi terhadap ketercapaian program pada setiap program yang dijalankan dipantau melalui indikator setiap program. Tim PKM bersama dengan tim mitra bersama-sama melaksanakan program sesuai dengan tahapan kegiatan dan indikator program. Pelaksanaan program dan indikator capaian dapat dilihat pada Tabel 1.

Tabel 1. Pelaksanaan program dan indikator capaian

\begin{tabular}{ll}
\hline \multicolumn{1}{c}{ Program } & \multicolumn{1}{c}{ Indikator } \\
\hline $\begin{array}{l}\text { Pembuatan pakan ayam berbentuk pelet } \\
\text { dengan bahan baku limbah sayur }\end{array}$ & Formulasi pakan berbentuk pelet dari limbah sayur \\
$\begin{array}{l}\text { Pelatihan untuk peningkatan keterampilan } \\
\text { pembuatan pakan menggunakan mesin } \\
\text { pembuat pelet }\end{array}$ & $\begin{array}{l}\text { Pembuatan pelet menggunakan mesin pelet dengan } \\
\text { engine mesin berbahan bakar bensin dan diameter } \\
\text { lubang keluaran } 1,5 \mathrm{~mm}\end{array}$ \\
$\begin{array}{l}\text { Peningkatan kualitas dan pengelolaan } \\
\text { produksi ayam broiler }\end{array}$ & $\begin{array}{l}\text { Peningkatan kualitas pengelolaan ayam broiler } \\
\text { dengan evaluasi bobot badan, penurunan mortalitas, } \\
\text { dan peningkatan FCR. }\end{array}$ \\
\hline
\end{tabular}

Penerapan teknologi dalam program pengabdian masyarakat ini adalah dengan mengolah limbah sayur menjadi pakan pelet. Pelet merupakan suatu bentuk pakan yang dibuat menjadi ukuran tabung dengan diameter $5 \mathrm{~mm}$ dan panjang 3-4 $\mathrm{mm}$. Dalam pelaksanaan pengabdian masyarakat ini, digunakan 3 jenis sayur yaitu kubis, daun kol putih, dan sawi. Alasan digunakannya ketiga jenis sayur tersebut karena jenis sayur ini jumlahnya lebih banyak dibandingkan jenis limbah sayur lainnya. Tahapan yang dilakukan pada pembuatan pelet dari limbah sayur yaitu:
1. Menyusun formulasi pakan ayam broiler menggunakan menggunakan limbah sayur yaitu daun kol putih $50 \%$, kubis $25 \%$, dan sawi $25 \%$.

2. Mencacah limbah sayur menjadi kecilkecil, dan mengeringkannya di bawah sinar matahari selama 1 hari. Tujuannya adalah untuk menurunkan kadar airnya, sehingga akan memperpanjang daya simpan dan kemudahan dalam pengolahan selanjutnya (Bakshi, 2016).

3. Sebanyak $15 \%$ dari campuran limbah sayur tersebut dicampur dengan bahan-bahan pakan lainnya yaitu jagung $56,5 \%$, tetes 
tebu $1 \%$, tepung kanji $4,5 \%$, tepung daging $20,3 \%$, limbah sayur $15 \%$, premix broiler $2 \%$, dan minyak 0,7\%. Penambahan sebanyak $15 \%$ limbah sayur tersebut, telah didasarkan atas penelitian sebelumnya yang dilakukan oleh tim, sehingga dapat menghasilkan pakan yang sesuai untuk ayam broiler.

4. Memasukkan campuran bahan ke dalam mesin pelet, lalu memprosesnya menjadi bentuk pakan pelet, dan pelet yang telah jadi ditampung dalam tampah-tampah.

Pelet campuran limbah sayur dikeringkan di bawah sinar matahari hingga kering. Hasil pelet ini masih berukuran agak panjang, sehingga dalam pemberiannya sebagai pakan ayam, perlu dikurangi ukurannya dengan cara ditumbuk ringan untuk mencapai ukuran diameter $5 \mathrm{~mm}$ dan panjang 3-5 $\mathrm{mm}$. Pelet yang dihasilkan tersebut mempunyai kandungan nutrisi yang telah sesuai untuk ayam broiler yaitu $2936 \mathrm{kkal} / \mathrm{kg}$ energi; $19,28 \%$ protein; $6,98 \%$ lemak; dan 4,029\% serat. Salah satu keberhasilan dari pemanfaatan limbah sayur dalam pelet ayam adalah peningkatan kualitas ayam yang diternakkan oleh kelompok tani yaitu nilai FCR, bobot badan, dan tingkat mortalitas. Parameter pengamatan FCR menunjukkan tingkat efisiensi pakan terhadap pembentukan daging. FCR atau feed convertion ratio diukur dengan menggunakan rumus :

$$
\mathrm{FCR}=\frac{\text { Jumlah konsumsi ayam mulai DOC hingga umur } 40 \text { hari rata-rata per ekor }}{\text { Bobot badan umur } 40 \text { hari rata-rata per ekor }}
$$

Pengukuran bobot badan dilakukan pada umur 40 hari (saat panen), yaitu dengan mengukur semua bobot badan masing-masing ayam broiler sebanyak 100 ekor, kemudian dari bobot badan yang ada di rata-rata dengan cara membaginya dengan jumlah populasi ayam. Sedangkan peningkatan bobot karkas, diukur dari bobot hidup ayam dikurangi dengan berat darah, berat kaki bagian lulut hingga jari, berat bulu, berat kepala, berat tembolok, dan berat organ-organ dalam. Pengukuran bobot karkas dilakukan pada umur 40 hari ketika ayam panen dan disembelih.

$$
\text { Bobot badan rata-rata }=\frac{\text { Jumlah keseluruhan bobot badan ayam }}{\text { jumlah ayam }}
$$

Parameter mortalitas atau kematian ayam diamati dengan melihat kondisi ayam broiler secara harian, dimana tingkat mortalitas $0 \%$ yang artinya ayam broiler yang dipelihara sejak DOC hingga panen (umur 40 hari) tidak terdapat kematian sama sekali. Pemberian pelet berbasis limbah sayur tidak memberikan dampak terhadap kesehatan.

Monitoring dan evaluasi kegiatan dan parameter dilakukan pada setiap tahapan kegiatan dan setiap tahapan pengukuran parameter. Monitoring yang dilakukan meliputi:

1. Monitoring bahan-bahan limbah sayur yang akan digunakan dalam pembuatan pelet. Limbah sayur dipilih yang masih layak digunakan dengan kriteria masih cukup segar, tidak berlendir, dan tidak berbau busuk. Hal ini mengingat limbah akan digunakan untuk pakan unggas yang harus memperhatikan kesehatan ternak.

2. Monitoring pembuatan pelet. Monitoring dilakukan saat pencampuran limbah sayur dengan pelet yaitu saat memasukan bahanbahan ke dalam mesin pelet hingga keluar menjadi pelet. Pencampuran limbah harus dilakukan dua kali dengan tujuan agar bahan- bahan pakan dan mineral yang berjumlah sedikit dapat terikat secara merata (homogen) dengan limbah sayur.

3. Monitoring dilakukan terhadap kandang, dimana kandang harus memenuhi standar pemeliharaan, kebersihan, dan keamanan unggas.

4. Monitoring terhadap fase pemeliharan. Seperti diketahui fase ayam broiler terbagi menjadi 2 yaitu fase starter dan finisher. Fase starter adalah ayam umur 1 hari (DOC) hingga 21 hari, sedangkan fase finisher adalah ayam umur 22 hingga panen (40 hari). Proses adaptasi terhadap pakan dilakukan secara bertahap yaitu mulai diperkenalkannya pelet limbah sayur pada umur ayam 14 hari hingga umur 20 hari. Saat adaptasi tersebut, ransum yang diberikan masih berupa campuran antara pelet limbah sayur dengan pakan BR0. Ayam yang telah berumur 21 hari diberikan pelet limbah sayur $100 \%$ tanpa tambahan pakan pabrik. Selama pemeliharaan ini ayam dicatat perkembangannya secara harian mulai dari kondisi kesehatan ayam, tingkat konsumsi harian ayam, bobot badan perminggu dan 
bobot badan panen. Selama pemeliharaan, tidak didapati ayam yang sakit ataupun mencret terutama saat pemberian pakan pelet. Bahkan hingga panen tidak terdapat kematian. Hal ini menunjukkan bahwa penggunaan pakan pelet tidak memberikan dampak yang buruk terhadap kesehatan unggas.

Evaluasi dilakukan dengan membandingkan hasil penerapan kegiatan pengabdian pada masyarakat dengan kondisi sebelumnya

\begin{tabular}{|c|c|c|}
\hline No & Sebelum kegiatan & Sesudah kegiatan \\
\hline 1 & $\begin{array}{l}\text { Peternak melakukan metode } \\
\text { coba-coba dalam } \\
\text { memberikan limbah sayur } \\
\text { dan limbah pakan yang lain } \\
\text { ke ayam broiler sebagai } \\
\text { pakan tambahan tanpa } \\
\text { membertimbangkan } \\
\text { kebutuhan nutrisi ternak }\end{array}$ & $\begin{array}{l}\text { Peternak dapat memformulasikan limbah sayur yang telah } \\
\text { dikeringkan, dicampur dengan bahan-bahan pakan lain } \\
\text { seperti jagung, bungkil kedelai, tepung daging, premiks } \\
\text { ayam, dan minyak untuk diformulasikan menjadi pakan } \\
\text { unggas sesuai kebutuhan ternak, sehingga mampu memenuhi } \\
\text { kebutuhan energi dan protein unggas serta meningkatkan } \\
\text { produksi ayam secara seragam }\end{array}$ \\
\hline 2 & $\begin{array}{l}\text { Limbah sayur tidak bisa } \\
\text { disimpan dan cenderung } \\
\text { cepat busuk, apalagi saat } \\
\text { musim penghujan, sehingga } \\
\text { bisa menimbulkan polusi } \\
\text { lingkungan dan akan sangat } \\
\text { bahaya jika diberikan } \\
\text { langsung ke unggas. }\end{array}$ & $\begin{array}{l}\text { Terciptanya teknologi pembuatan pakan menjadi pelet } \\
\text { merupakan alternatif teknologi yang efisien karena pakan } \\
\text { dari limbah sayur dapat disimpan dalam jangka waktu lebih } \\
\text { dari } 2 \text { bulan. Hal ini akan memudahkan juga dalam segi } \\
\text { penyimpanan dan stok pakan ketika harga pakan naik. }\end{array}$ \\
\hline 3 & $\begin{array}{l}\text { Peternak melakukan } \\
\text { pencampuran pakan setiap } \\
\text { hari untuk diberikan kepada } \\
\text { unggas }\end{array}$ & $\begin{array}{l}\text { Peternak tinggal memberikan pakan pelet berbasis limbah } \\
\text { sayur yang sudah jadi kepada ternaknya, dikarenakan } \\
\text { peternak dapat membuat stok pakan unggas lebih banyak dan } \\
\text { disimpan dalam jangka waktu yang lama }\end{array}$ \\
\hline 4 & $\begin{array}{l}\text { Peternak harus sering-sering } \\
\text { mencari sumber pakan dari } \\
\text { warung-warung ataupun } \\
\text { pasar dan tidak bisa } \\
\text { menyimpannya dalam } \\
\text { jangka waktu yang lama } \\
\text { dikarenakan pakan cepat } \\
\text { mengalami pembusukan }\end{array}$ & $\begin{array}{l}\text { Proses pembuatan pelet dengan menggunakan mesin yang } \\
\text { ada mampu menghasilkan } 5 \mathrm{~kg} \text { pelet dalam bentuk basah per } \\
\text { menitnya, atau sekitar } 300 \mathrm{~kg} \text { berat basah setiap jamnya, dan } \\
\text { kemudian agar lebih kering peternak dapat mengeringkannya } \\
\text { di bawah sinar matahari. Setelah pelet kering, maka peternak } \\
\text { dapat menyimpannya dalam waktu yang lama }\end{array}$ \\
\hline 5 & $\begin{array}{l}\text { Belum ada mesin pembuatan } \\
\text { pelet pakan ayam }\end{array}$ & $\begin{array}{l}\text { Mesin pelet telah tersedia dan dapat dioperasionalkan dengan } \\
\text { baik. Mesin pelet menggunakan bahan bakar bensin, bersifat } \\
\text { sangat fleksibel digunakan dan murah, bahkan peternak } \\
\text { dapat memindahkan mesinnya dengan mendekati } \\
\text { keberadaan sumber pakan yang ada dalam membuat pakan }\end{array}$ \\
\hline
\end{tabular}

\section{HASIL DAN PEMBAHASAN}

Penerapan teknologi dalam program pengabdian masyarakat ini adalah dengan mengolah limbah sayur menjadi pakan pelet. Pelet pakan ayam broiler yang dimaksud dalam kegiatan pengabdian masyarakat ini adalah pelet pakan ayam yang berbentuk tabung dengan diameter $5 \mathrm{~mm}$ dan panjang 3-4 $\mathrm{mm}$. Keuntungan yang diperoleh dari pembuatan pakan dalam bentuk pelet tersebut yaitu:
1. Bentuknya sesuai dengan paruh dari ayam sehingga memudahkan unggas dalam mengambil pakan.

2. Pakan yang dibuat menjadi pelet akan memiliki daya simpan yang lama, bahkan berbulan-bulan dalam plastik pengemas atau karunng pakan, karena sudah dalam bentuk yang kering. Hal ini menjadi alasan utama, pakan pelet dapat mengatasi sejumlah limbah sayur yang cukup banyak setiap harinya dan meminimalkan pembuangan. Dalam kondisi kering, daya 
simpan produk menjadi lebih panjang daripada disimpan dalam bentuk basah. Hasil penelitian García et al. (2005) menyatakan bahwa limbah sayur mengandung kadar air sebesar $60-80 \%$, sehingga harus dikeringkan.

3. Menghindari pakan yang menyebabkan debu ketika dikonsumsi oleh ayam, sehingga akan menurunkan potensi penyakit yang berkaitan dengan saluran pernafasan

4. Pembuatan pakan pelet dari limbah sayur dapat menurunkan biaya pakan, karena limbah sayur ini dapat diperoleh secara gratis. (Mahgoub et al., 2018) juga menegaskan bahwa jika menggunakan limbah sayur sebagai bahan baku pakan ternak, maka akan menghemat biaya untuk pembelian pakan pabrik dan harapannya dapat meningkatkan pendapatan peternak.

5. Peternak maupun petani ataupun pedagang yang berkecimpung dalam pemeliharaan ternak, dapat menimbun pakan dalam jumlah banyak untuk berjaga-jaga ketika harga pakan naik.

Peternak diberikan pengetahuan dan keterampilan untuk pembuatan dan pemberian pakan sesuai ransum pada ayam broiler yang diternaknya. Selama pemeliharan ayam broiler, pakan diberikan secara ad libitum. Bibit DOC ayam broiler peternak pada umur 1 hingga 2 minggu diberikan pakan BR0, kemudian pada umur 3 minggu hingga panen (40 hari) diberikan pakan pelet limbah sayur. Pakan diberikan di dalam tempat pakan dan berdekatan dengan tempat minum. Selama masa pemeliharaan, ayam diberi vitamin vitachiks dan diberikan vaksin ND-IB saat umur 5 hari, Gumboro saat umur 7 hari, dan ND saat umur 14 hari. Pencatatan bobot badan dilakukan setiap minggu dengan mengambil sampling ayam sebanyak $10 \%$. Selama pemeliharaan, ayam dihitung jumlah konsumsi dan bobotnya sebagai dasar untuk menghitung FCR (Feed Consumption Ratio) atau efisiensi pakan terhadap bobot badan. Capaian program didasarkan pada indikator yang dapat dilihat pada Tabel 2 .

Tabel 2. Capaian program didasarkan pada indikator

\begin{tabular}{|c|c|c|}
\hline Program & Indikator & Capaian Indikator \\
\hline $\begin{array}{l}\text { Pembuatan pakan } \\
\text { ayam berbentuk pelet } \\
\text { dengan bahan baku } \\
\text { limbah sayur }\end{array}$ & $\begin{array}{l}\text { Formulasi pakan } \\
\text { berbentuk pelet dari } \\
\text { limbah sayur }\end{array}$ & $\begin{array}{l}\text { Formulasi pakan ayam broiler menggunakan } \\
\text { campuran limbah sayur yaitu daun kol putih } \\
50 \% \text {, kubis } 25 \% \text {, dan sawi } 25 \% \text {. Sebanyak } \\
15 \% \text { dari campuran limbah sayur tersebut } \\
\text { dicampur dengan bahan-bahan pakan ayam } \\
\text { broiler lainnya yaitu jagung, bungkil kedelai, } \\
\text { tepung daging, premiks ayam, dan minyak }\end{array}$ \\
\hline $\begin{array}{l}\text { Pelatihan untuk } \\
\text { peningkatan } \\
\text { keterampilan } \\
\text { pembuatan pakan } \\
\text { menggunakan mesin } \\
\text { pembuat pelet }\end{array}$ & $\begin{array}{l}\text { Pelatihan menggunakan } \\
\text { mesin pembuat pelet } \\
\text { dengan engine mesin } \\
\text { berbahan bakar bensin } \\
\text { dengan diameter lubang } \\
\text { keluaran } 1,5 \mathrm{~mm}\end{array}$ & $\begin{array}{l}\text { Peningkatan keterampilan peternak dalam } \\
\text { menggunakan mesin pembuat pelet yang } \\
\text { mempunyai spesifikasi mesin semi otomatis, } \\
\text { dengan fungsi mencetak pelet dengan diameter } \\
1,5 \mathrm{~mm} \text {. Mesin tersebut mempunyai kapasitas } \\
\text { produksi pelet yaitu } 15 \mathrm{~kg} / \mathrm{jam} \text {. }\end{array}$ \\
\hline $\begin{array}{l}\text { Peningkatan kualitas } \\
\text { dan pengelolaan } \\
\text { produksi ayam broiler }\end{array}$ & $\begin{array}{l}\text { Peningkatan kualitas } \\
\text { pengelolaan ayam } \\
\text { broiler dengan evaluasi } \\
\text { bobot badan, penurunan } \\
\text { mortalitas, dan } \\
\text { peningkatan FCR. }\end{array}$ & $\begin{array}{l}\text { Pelet limbah sayur untuk pemeliharaan ayam } \\
\text { broiler, memberikan hasil efisiensi pakan } \\
\text { (FCR) sebesar 2,12; tingkat mortalitas 0\%; } \\
\text { serta peningkatan bobot badan sebesar } \\
1265,583 \text { gram. }\end{array}$ \\
\hline
\end{tabular}

Hasil dari pelaksanaan pengabdian masyarakat dari penggunaan pelet limbah sayur untuk pemeliharaan ayam broiler ternyata berimbas terhadap pengolahan limbah sayur dan peningkatan hasil produksi ayam. Limbah sayur yang tidak terpakai lebih banyak dibuang atau dibiarkan membusuk, sehingga berpengaruh terhadap lingkungan, dan jika limbah yang mendekati busuk diberikan ke ternak dapat menyebabkan ternak menjadi sakit, sehingga pemilik ternak akan mengalami kerugian. Olahan pelet dari limbah sayur yang tidak terpakai berakibat pada terhindarnya sayuran menjadi busuk dan terhindarnya pembuangan ke 
lingkungan. Proses pembuatan pelet dari limbah sayur hingga pemberian pakan pada ayam, dapat dilihat pada Gambar 1 dan pelatihan pembuatan pelet bersama peternak, dapat dilihat pada Gambar 2.

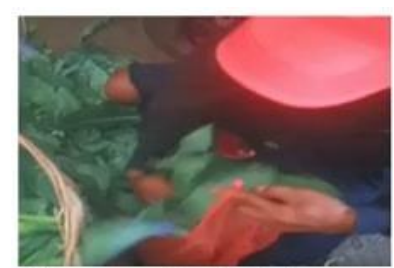

Pengumpulan limbah sayur

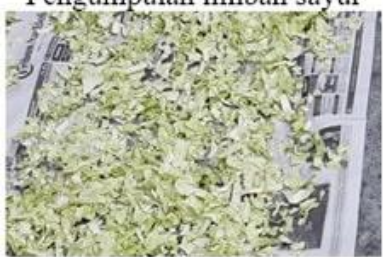

Penjemuran cacahan sayur

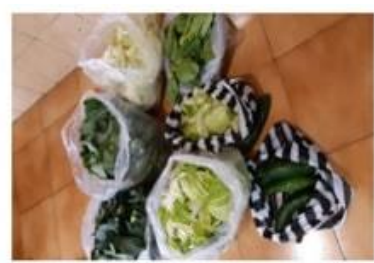

Limbah sayur

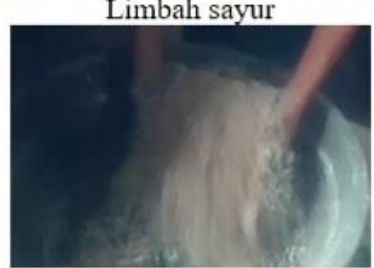

Pencampuran

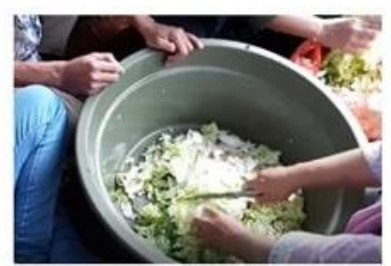

Pencacahan limbah sayuran

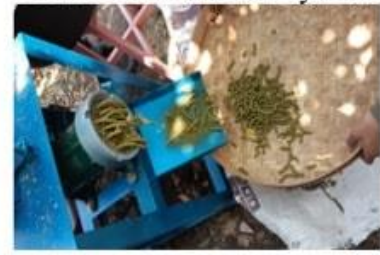

Pencetakan pelet dengan mesin

Gambar 1. Proses pembuatan pelet dari limbah sayur
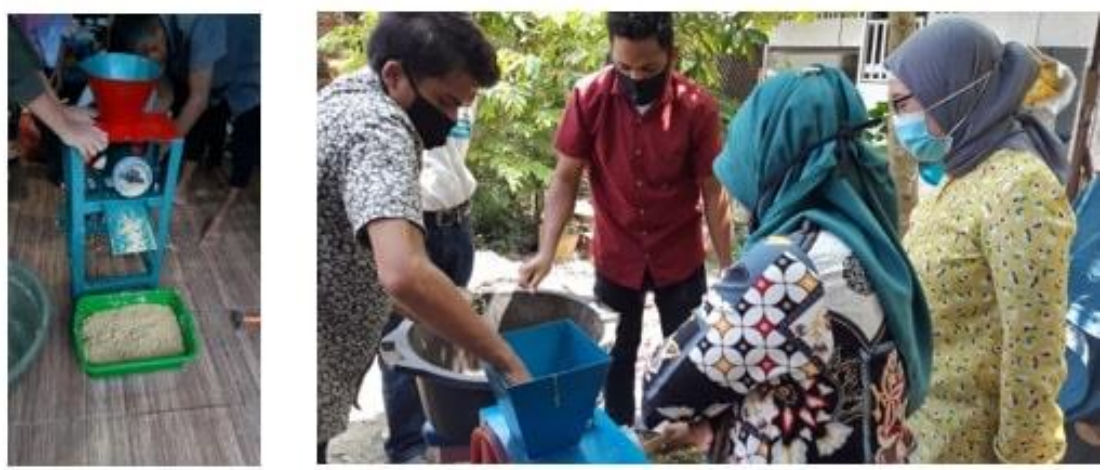

Gambar 2. Mesin pelet dan pelatihan pembuatan pelet bersama peternak

Dampak dari kegiatan pengabdian pada masyarakat diantaranya peternak yang awalnya melakukan metode coba-coba dalam memberikan limbah sayur ke ayam broiler sebagai pakan tambahan tanpa membertimbangkan kebutuhan nutrisi ternak, saat ini telah dapat memformulasikan limbah sayur yang telah dikeringkan. Limbah sayur tersebut dicampur dengan bahan-bahan pakan lain seperti jagung, bungkil kedelai, tepung daging, premiks ayam, dan minyak untuk diformulasikan menjadi pakan unggas sesuai kebutuhan ternak. Selain itu, limbah sayur yang awalnya tidak bisa disimpan dalam jangka waktu yang lama dan sifatnya memakan tempat serta mengundang hewan dan serangga, sehingga berdampak ke kesehatan manusia, seperti polusi bau, belatung, dan lain-lain, sudah dapat diatasi. Saat ini telah tercipta teknologi pembuatan pakan menjadi pelet yang merupakan alternatif teknologi yang efisien karena pakan dari limbah sayur dapat disimpan dalam jangka waktu lebih dari 2 bulan. Hal ini akan memudahkan juga dalam segi penyimpanan dan stok pakan ketika harga pakan naik.

Hasil dari pelaksanaan pengabdian masyarakat ini terhadap kualitas ayam broiler yang dihasilkan oleh peternak yaitu dapat memberikan hasil terhadap tingkat efisiensi pakan atau FCR sebesar 2,12 yang artinya untuk membentuk 1 gram daging diperlukan pakan sebanyak 2,1 gram, tingkat mortalitas $0 \%$, dapat menghasilkan bobot badan sebesar 1265.583 gram yang masih masuk dalam standar berat ayam pedaging yaitu $1,2 \mathrm{~kg}$. Selain itu, berdasarkan perhitungan harga pakan yang menggunakan limbah sayur adalah berkisar $\mathrm{Rp}$ 4600 per $\mathrm{kg}$. Harga tersebut jauh lebih murah dibandingkan pakan pabrik yang berkisar Rp 7000 per $\mathrm{kg}$.

\section{KESIMPULAN}

Berdasarkan hasil kegiatan pengabdian kepada masyarakat ini, disimpulkan bahwa pelet pakan ayam yang terbuat dari limbah sayur dapat 
menjadi pakan ayam broiler yang dapat digunakan oleh peternak untuk mengurangi harga pembelian pakan pabrik. Pelet dari limbah sayur tersebut mempunyai harga Rp 4600 per kg, yang lebih murah dibandingkan dengan pelet pabrik yaitu Rp 7000 per kg. Hasil kegiatan menunjukkan bahwa terjadi peningkatan pengetahuan dan keterampilan dalam pengelolaan usaha tani yang lebih baik pada pemanfaatan limbah sayur menjadi pelet pakan ayam broiler, peningkatan keterampilan untuk menghasilkan pelet pakan menggunakan mesin pembuat pelet, dan peningkatan kualitas pengelolaan ayam broiler dengan evaluasi bobot badan, penurunan mortalitas, dan peningkatan FCR.

\section{UCAPAN TERIMA KASIH}

Terimakasih disampaikan atas pendanaan kegiatan Pengabdian kepada Masyarakat yang dibiayai oleh Direktorat Riset dan Pengabdian Masyarakat, Deputi Bidang Penguatan Riset dan Pengembangan, Kementerian Riset dan Teknologi/Badan Riset dan Inovasi Nasional Tahun 2020; Kelompok Tani Sumber Rejeki dan Siswandi; seluruh tim PkM dosen dan mahasiswa; Prodi TIP dan Peternakan FP UNITRI; serta semua pihak yang telah membantu terlaksananya kegiatan.

\section{DAFTAR PUSTAKA}

Abun, A., Rusmana, D., \& Saefulhadjar, D. (2007). Efek pengolahan limbah sayuran secara mekanis terhadap nilai kecernaan pada ayam kampung super JJ-101. Ilmu Ternak, 7(2), 81-86.

Bakshi, M. P. S., Wadhwa, M., \& Makkar, H. P. S. (2016). Waste to worth: vegetable wastes as animal feed. $C A B$ Reviews: Perspectives in Agriculture, Veterinary Science, Nutrition and Natural Resources, 11(12), 1-26. https://doi.org/10.1079/PAVSNNR20161 1012

Das, N. G., Huque, K. S., Amanullah, S. M., \& Makkar, H. P. S. (2019). Feeding of processed vegetable wastes to bulls and its potential environmental benefit. Animal Nutrition, 5(1), 87-94. https://doi.org/10.1016/j.aninu.2018.04.002

García, A. J., Esteban, M. B., Márquez, M. C., \& Ramos, P. (2005). Biodegradable municipal solid waste: Characterization and potential use as animal feedstuffs.
Waste Management, 25(8), 780-787. https://doi.org/10.1016/j.wasman.2005.01.006

Lowisada, S. A. (2014). Bawang merah (studi kasus di Kelurahan Sukomoro Kecamatan Sukomoro). Ilmu Ekonomi, 2(2), 3-17.

Mahgoub, O., Kadim, I. T., Eltahir, Y., AlLawatia, S., \& Al-Ismaili, A. M. (2018). Nutritional value of vegetable wastes as livestock feed. Sultan Qaboos University Journal for Science [SQUJS], 23(2), 7884.

https://doi.org/10.24200/squjs.vol23iss2p p78-84

Md Salim, N. S., Singh, A., \& Raghavan, V. (2017). Potential utilization of fruit and vegetable wastes for food through drying or extraction techniques. Novel Techniques in Nutrition \& Food Science, 1(2), 15-27. https://doi.org/10.31031/ntnf.2017.01.00 0506

Mulyono. (2014). Membuat MOL dan kompos dari sampah rumah tangga. PT Agromedia Pustaka.

Rusad, R. E., \& Santosa, S. (2016). Pemanfaatan limbah sayur kubis (Brassica oleracea) dan buah pepaya (Carica papaya) sebagai pakan cacing tanah Lumbricus rubellus. Jurnal Biologi Makassar (BIOMA), 1(1), 8-15.

Samad, M. Y. (2006). Pengaruh penanganan pasca panen terhadap mutu komoditas hortikultura. Sains Dan Teknologi Indonesia, 8(1), 31-36.

Siswadi. (2007). Penanganan pasca panen buahbuahan dan sayuran. INNOFARM: Jurnal Inovasi Pertanian, 6(1), 68-71.

Sunarminto, B. H. (2010). Pertanian terpadu untuk mendukung kedaulatan pangan nasional. BPFE.

Superianto, S., Harahap, A. E., \& Ali, A. (2018). Nilai nutrisi silase limbah sayur kol dengan penambahan dedak padi dan lama fermentasi yang berbeda. Jurnal Sain Peternakan Indonesia, 13(2), 172-181. https://doi.org/10.31186/jspi.id.13.2.172-181

Truong, L., Morash, D., Liu, Y., \& King, A. (2019). Food waste in animal feed with a focus on use for broilers. International Journal of Recycling of Organic Waste in Agriculture, 8(4), 417-429. https://doi.org/10.1007/s40093-019-0276-4

Widjajanti, K. (2011). Model pemberdayaan masyarakat. Jurnal Ekonomi Pembangunan, 12(1), 15-27. 